\title{
Coherence of Work Based Learning and Regional Development in Latvia
}

\author{
Ilze Buligina ${ }^{1}$, Romans Putans ${ }^{2}$, Biruta Sloka ${ }^{3},{ }^{1-3}$ University of Latvia
}

\begin{abstract}
Integration of young people into the labour market is an issue of a high priority. The youth unemployment problem has explicit links to the vocational education and training (VET) system. Since 2009 there is an ongoing reform in the Latvian VET system. In this respect also the role of local governments increases. The paper addresses the issue of introducing innovative approaches in the Latvian VET system. The aim of the study is to estimate the overall readiness of public administrations to implement VET reforms within regional economic development in the context of the EU and national strategic priorities.
\end{abstract}

Keywords: VET reform, national strategic planning, regional development, youth, work-based learning.

\section{INTRODUCTION}

Integration of young people into the labour market is an issue of critically high priority in the entire European Union (EU) and in Latvia, too. The youth unemployment level in Latvia was as high as $28.4 \%$ according to EUROSTAT data in 2012. Education and training, as well as the first job experience for young people are considered to be crucial to start their employment career. Getting off to a good start facilitates youth integration into the world of work and lays the foundation for a good career, while it can be difficult to catch up after an initial failure [40]. The public administrations need to seek solutions at both national and regional level in order to address the problem in a systemic manner [4]. The importance of this issue is strongly emphasized in the EU and member states' national strategic planning documents, e.g. flagship initiative of the EU-2020 strategy Youth on the Move - a comprehensive package of policy initiatives on education and employment for young people in Europe. Narrowing down to ministries, active labour market policy measures by the Latvian Ministry of Welfare are set to promote youth employment and to provide opportunities to young unemployed. The issues have also been studied worldwide in academic research [32], [6], [47] where the findings could be useful for policy makers on different aspects including regional development [9], [7], development of different branches of national economies [34]. Experience of decades (thirty years) in changing of approaches [33] and different fields [18] in vocational education have been observed in academic research. Quality assurance has great importance in vocational education [19] as well as the issues of employability [21], on aspects of importance and different approaches of cooperation of vocational schools and industry [22].

The youth unemployment problem has explicit links to the vocational education and training (VET) system within which lower and medium qualification specialists are prepared for the labour market [42]. Since 2009 there is an ongoing reform in the Latvian VET system aiming at training workforce in compliance with the labour market needs and economic development trends. A current proposed innovation is the adaption of dual system elements for piloting work-based learning approaches in cooperation with local employers. Recent research indicates the presence of the multifaceted relationship between the actual learning environment and its capability to educate skilled workforce, linking it to the ability to get involved in the innovation process [39]. During the recent years, the European Commission has carried out the analysis of the involvement of the Member States in work-based learning, pointing out the differences in the approaches of the Member States and the effectiveness of various solutions [16].

The paper addresses the issue of introducing work-based learning elements in the Latvian VET system by studying the opinions of entrepreneurs regarding the feasibility and usefulness of the approach. The aim of the study is to estimate the overall readiness of entrepreneurs to implement VET reforms in the context of regional economic development and to link them with the achievements expected in the national and regional strategic development plans.

\section{STRATEGIC FRAMEWORK AND THEORETICAL PERSPECTIVE}

In order to structure the main topics discussed in the present paper, namely, regional development, national strategic planning, youth integration, VET and their interconnections, the first part of this chapter describes the legislative and strategic framework of these topics and identifies their positions in the hierarchically highest supranational and national-level long-term and medium-term planning document, as well as their sequent breakdown in more specific programmes of activities, while the second part of this chapter shows the results of academic research on the problem of implementation of innovation in relation to public policies.

Vocational education and training systems in the European Union started to gain their enhanced strategic recognition in late 2002 with the Copenhagen process or "The Copenhagen Declaration" [44] when it was recognized as a crucial and integral part of Lisbon strategy, notably in terms of promoting social inclusion, cohesion, mobility, employability and competitiveness, and the EU Member States decided on enhanced cooperation in vocational education and training. The Council of the EU after Copenhagen Declaration came up with the Resolution on the promotion of enhanced European cooperation in vocational education and training [44]. The resolution noted that the adaptability and employability of young people and adults, including older workers, depend strongly on access to high-quality initial education and training and the opportunity to update and acquire new skills throughout 
working life, and that vocational education and training systems play a key role in providing competences and qualifications thus developing a knowledge-based Europe [2].

Today the European Union's ten-year growth strategy "Europe 2020" is explored as the upper supranational long-term planning document. Since it represents the core values of the existence and the development of the European Union, which at a large scale has always been about cohesion, then the focus on regional development is visible in nearly every element of this strategic planning document and a number of policies, programmes and initiatives are set and planned to facilitate regional development in the EU in numerous and varied dimensions. As for vocational education and training, the Strategy expects the EU Member States to improve educational outcomes on a national level, addressing each segment, including VET, while the European Commission itself promises to give a strong impetus on the EU level to the strategic framework for cooperation in education and training involving all stakeholders thus reinforcing the attractiveness of vocational education and training [10]. As for integration and development of young people, the EU-2020 Strategy considers young people, their integration and their involvement as an essential part to achieve the goals of the Strategy and as a strong precondition for Europe`s future prosperity. The strongest focus on the young people of the EU-2020 Strategy is defined in one of its flagship initiatives - Youth on the Move [11], which is the second supranational strategic planning document to be explored in this chapter. Although it primarily contains a number of policy initiatives for the development and involvement of young people, it is also connected to regional development through examining of how to support youth employment, educational opportunities and higher education infrastructure [24]. The development and integration of young people is mainly seen through facilitation of education, training and employment and providing adequate social safety in different paths of young people`s lives and their involvement [30], as well as avoiding adoption of different approach based on gender [1], different vocational education levels as well as payment systems [2]. As for vocational education and training, within the Youth on the Move initiative the European Commission is promoting apprenticeship-type vocational training and high quality traineeships as workplace learning experience thus building bridges to the labour market.

Another cross-dimensional aspect for interconnectivity of regional development and VET is defined in the following statement of the European Commission, "A new impetus for European cooperation in Vocational Education and Training to support the Europe 2020 strategy" [12] that promotes international cooperation in the area of VET, including Neighborhood and Enlargement countries where different approaches are applied [9]. This cooperation in its turn is linked to the potential to contribute to the extended transnational collaboration and regional development. This communication contributes to the Europe 2020 Strategy by reinforcing the attractiveness of vocational education and training making a distinction between initial and continuing vocational education and training, where initial (IVET) is to equip young learners with skills directly relevant to evolving labour markets [5].

Also the Agenda for new skills and jobs [13] emphasizes the need to improve the attractiveness of initial vocational education and training and encourages employers to co-invest and participate in the activities of education, particularly in vocational education and training to facilitate the provision of work-based learning. Young people are targeted as one of the most vulnerable social groups for integration into the labour market that need specifically adopted targeted approaches, providing them with the possibilities to obtain "the right mix of skill". Regional development aspects are not specifically stressed in this Agenda, however, it highlights the necessity and effectiveness of partnerships, involvement, and co-operation also on the regional and interregional level.

One of the newest associated calls to action from the European Commission is "Working together for Europe's young people: A call to action on youth unemployment." [14] It contains country-specific recommendations for better employment, in particular that of young people. The European Commission has recommended to 16 Member States, including Latvia, to focus on reforming vocational and educational training programmes by increasing their labour market relevance through a stronger work-based learning component and accelerating the reform of apprenticeships with the help of the EU budget. Among other recommendations, the European Commission suggests Latvia to tackle long-term and youth unemployment by increasing coverage and effectiveness of active labour market policies, improve the employability of young people through a Youth Guarantee (European Youth Guarantee is a guarantee that ensures that every young person in Europe is offered a job, further education or work-focused training at the latest four months after leaving education or after becoming unemployed) [15] and implement reforms in the field of vocational education and training.

Another international contribution to facilitation of youth employment by enhancing vocational education and training is Framework of Actions on Youth Employment [17] established by European Social Partners [45]. This initiative also features the need of regional involvement and primarily highlights the challenges and the potential of young people integration into the labour market, in particular, promoting and identifying Social Partners' short- and long-term actions for the development and wider use of vocational education and training using also workbased learning models.

Also the EU Strategy for Youth, Strategic Framework for European cooperation in education and training and a number of other EU level strategic planning documents and programmes emphasizes the need, the role and the positive impact of vocational education and training on the overall development of welfare of the EU, including regional development, increase of competitiveness through targeted education and integration of young people into the labour market.

National Reform Programme of Latvia for Implementation of the "Europe 2020" Strategy can be considered as EU level strategic planning document mapping to the national level. 
Within regional development dimension of the Programme, the main focus is given to regional mobility that is one of the measures for decreasing the risk of structural unemployment in Latvia as well as for strengthening the capacity of municipalities in attraction of companies and investments. The programme according to EU-2020 Strategy provisions focuses also on young people that are targeted as one of the most vulnerable social groups for integration into the labour market by introducing new measures targeted at young unemployed for a practical work trial and for voluntary work under active labour market policy measures, which are described further in this chapter. Structural changes in vocational education are planned by optimizing and differentiating the number and location of vocational education institutions in the regions (from 56 institutions in 2010 to 29 in 2015), thus developing materialtechnical supply of vocational education that conforms to the current requirements and improving the quality of vocational education. Strengthening the cooperation with social partners to improve and develop vocational education and thus ensuring the increase of the share of qualified labour are among the measures set in the Programme [37].

On the national level in Latvia two main strategic planning documents - National Development Plan of Latvia 2014-2020 and Sustainable Development Strategy of Latvia until 2030 are explored to identify further breakdown of the provisions set in the EU level strategic planning documents and as well as to identify national priorities regarding interconnectivity of regional development, youth involvement and vocational education and training. National Development Plan of Latvia 2014-2020 (NDP), which is hierarchically the highest nationallevel medium-term planning document and which is closely related to the Sustainable Development Strategy of Latvia until 2030 and the National Reform Programme for the Implementation of the EU-2020 Strategy, emphasizes the potential of regions, particularly in the sector of small and medium sized enterprises that provide jobs to the regional population. Youth employment and youth education are also among the strongest priorities of National Development Plan stating that compulsory secondary education, both general and vocational, is instrumental to achieving an "economic breakthrough" and a high standard of living in 2020. One of the goals of NDP is based on international trends and labour market projections to create an adaptive and competitive system of vocational education and to come to the ratio of students in general secondary education and vocational education programmes after completing elementary education to $50 / 50$ by 2020, while in 2013 the ratio is around 60/40. Among the individual measures of NDP there are such activities as integration of young people into the labour market following the completion of vocational or higher education, including business start-ups, improvement of the infrastructure and facilities of vocational education institutions. At the same time NDP admits that intensive improvements to vocational education are needed, which creates employment opportunities and is important for enhancing the structure of the national economy. The improvement of the competencies of the teachers and work experience of advisers involved in vocational education in accordance with the trends of the labour market as well as the capacity building of vocational education institutions (including teachers) with respect to adult education is also anticipated in Latvian NDP [36].

Similar to the EU Agenda for new skills and jobs on the EU level, the Sustainable Development Strategy of Latvia until 2030 (Latvia 2030) on the national level stresses the need for cooperation between education and regional entrepreneurship educational institutions in co-operation with regional entrepreneurs should be aware of local and global tendencies in the national economy in order to be able to foresee and offer such content and format of studies, which would promote regional development and the competitiveness of individuals and organizations in the economy of tomorrow. Latvia2030 also foresees the enlivening of the culture of lifelong education in the society that would increase the necessity and use of the possibilities for education and career-building throughout life, particularly for young persons. As for vocational education and training, Latvia 2030 identifies the existing and potential advantages of education system in Latvia, for instance, institutions of vocational education already have a good opportunity to develop training of adults as a stable action direction necessary for the society. Latvia has also the necessary potential to develop exportable creative industry on the basis of culture (festivals, movie production, computer games, music records, etc.), as well as to create design products with high added value. Having created a competitive offer of cultural and educational programmes in music, visual art, cinema, architecture, etc., Latvia has relatively good opportunities to export also vocational secondary and higher education in cultural and creative professions. The Strategy also stresses the need to increase the prestige of vocational education and training and to continuously improve skills and competences throughout the work life by adult education and education at work places [43].

Active labour market policy measures (ALMPM) in Latvia within regional development dimension also focuses on the regional mobility of employees in order to tackle long-term unemployment in Latvia's regions. As for young people, ALMPM shows several subsidized employment measures, positioning young unemployed as the vulnerable group of unemployed people, as well as special measures for youth that give young unemployed a possibility to gain working experience, undergoing an internship or applying for voluntary work, and helping young unemployed with low level of education or without any work experience to make a conscious decision about future education or job field by giving a possibility to try three different short-term vocational education fields. On a large scale of ALMPM, vocational education and training is being offered to unemployed that includes different training programmes (continuing vocational training to acquire vocational qualification, advanced vocational training to reach vocational proficiency, non-formal and on-the-job training) organized in co-operation with educational institutions and employers only for registered unemployed and job-seekers [35]. 
Overall the strategic, legal and programming framework of vocational education and training in Latvia is well developed and goes strongly in line with provisions contained in the EU level planning document for development of vocational education and training, and in some cases may serve as a good case practice, still leaving space for further practical improvements and development, as well as challenges that Latvia is facing to increase the role and prestige of VET in the labour market. According to the study by Maliranta, M. et al. [31], employability is a great challenge to the initial vocational education and training. The findings for local business conditions give support to the view that measures of education policy do not suffice but need to be complemented with those of regional or employment policy, for example, policies aiming to increase regional mobility of the labour force [26]. It is also visible that Latvia follows the trend showed by comparative studies, i.e., vocational trainings have tended to focus on initial training and to a lesser extent on continuing vocational education undertaken by employed workers. Insofar as preemployment education and training activities are addressed, the focus of enquiry has tended to be restricted to the schooling and training of young people and different aspects of their transition from education to employment [25]. The new approach of dual education has been developed. The unemployed have tended to receive less attention, yet in many countries training is an important component of active labour market policy and tends to account for the largest share of the overall state expenditure on activation measures [20], the latter being also a challenge Latvia is trying to overcome.

However, in the context of the present paper the focus is on the integration of the issue of the employment of young people into the overall development activities at the regional level. This implies that also the local governments become an important stakeholder, which alongside (and in co-operation) with the local employers) are a key information source on the needs and priorities of that particular region. Being aware of the challenging nature of this task, which implies also the change of the existing attitudes and the introduction of innovative approaches to the current vocational education and training reform, our aim was both to study the relevant academic discourse and carry out a corresponding empirical study. In particular, we were focusing on the issues related to the workbased learning or dual training.

Dual or work-based approaches are viewed in academic discourse as a continuously developing approach (not only as such but also in relation to the present global and European economic downturn and the possibilities to offer solutions to this). Clearly, no system can stay intact, and it refers also to the traditional work-based approaches which undergo transformation and further development. It is claimed by Tynjala [46] that the increasing co-operation between the world of education and work will change the nature of learning in both contexts, regardless of the seemingly considerable differences between the two environments [20]. In the context of regional development the co-operation between the various actors is seen as an important pre-requisite for a successful economic development. It is becoming universally accepted that the number and types of involved parties is widening and increasing. Thus, Sotarauta [41] stresses that fragmented groups of actors are not in a position to influence the regional developments in a meaningful way, and only a coordinated 'pulling together' of actors, resources, competences, ideas and visions can create a new perception, also stressing the importance of awareness - not only the question what is to be done matters, but more importantly how and why it is to be done [21]. Various studies stress the local environments as the real sources of knowledge, expertise and potential solutions for successful and sustainable economic development regionally, also stressing the new role of local governments. Much depends on the open-mindedness and preparedness of local governments to accept innovation in vocational education and training and in local labour market development. Case studies have been presented on various innovative approaches as well, in attempt to address the issue of youth employment. For example, an innovative approach of travel (holidaymaking) with work-base destination has been presented and analyzed - emphasizing the benefits for both, the working travelers and the local (regional) economies [23]. It is suggested by authors that for sustainable regional development knowledge sharing is to be seen as an action of great potential both at individual and group level, including the development of social network platforms - in order to arrive jointly to innovative solutions by integrating a diversity of perspectives [27] including the development of vocational education networks. The authors increasingly tend to show the inherent importance of linking learning with action and stress the role of the mentoring process, thus securing a 'tool' for reflection, development, tackling change and giving the basis for the conversation with the mentor, which in its turn leads to reflection, learning and options for further action [29]. At the regional level the stakeholders involved will have to discover in mutual interaction what works and what action are needed, stressing that for sustainable regional development it is important to implement network learning among public, private and knowledge sectors [28]. This approach also lies at the basis of our empirical research, which is based on the study carried out by a group of researchers at Iecava Region of Latvia "Research of Needs of Iecava Municipality for Realisation of EU and other Financial Institutions Co-Financed Projects and Activities" [38]. During the study the role of local governments, entrepreneurs, educators and other stakeholders was analyzed from different perspectives including the role of coordinated local government activities with the local entrepreneurs in promoting and supporting innovative approaches in vocational education and training. The study was based on a pre-prepared and tested questionnaire. The present paper primarily focuses on the part of the study that concerns the opinions of local entrepreneurs in addressing the employment challenges of young people at local (regional) level. More details on the study and its relevant parts in the context of the present paper will be provided in the following chapters.

\section{RESEARCH APPROACH}

The main research methods used in the preparation of the paper have been statistical research methods, including 
quantitative and qualitative analyses, as well as other social research methods, such as literature review, content analysis, and logical-constructive analysis. For the implementation of the empirical research, a survey was conducted among entrepreneurs and other stakeholders in Iecava District in Latvia. The analysis of the opinions of the various target groups enabled to draw conclusions regarding the research problem based on which further practical recommendations for possible steps in policy making were prepared.

To carry out the empirical research on the above indicated issues, apart from the textual analysis (consisting of analysis of the current policy documents - reports by the European Commission, reports prepared by the OECD, the European Union strategic planning documents, case studies of national innovation and vocational training systems and other) and academic discourse regarding our research problem, an empirical study in the form of survey has been also carried out.

By means of empirical study the opinions of relevant stakeholders regarding the respective research problems have been analysed. For the implementation of the empirical study, a questionnaire was developed and entrepreneurs were asked relevant questions to evaluate the current situation and approaches regarding innovative solutions in vocational education and training, with an emphasis on work-based learning. For more detailed analysis of different approaches focus group discussions of municipality officials and other stakeholders were organized and the results were included in the paper.

Before the implementation of the survey, the questionnaire was tested among established professionals in the above mentioned fields. Evaluations had to be made on the scale 1-10, where 1: do not agree; 10: fully agree. Based on the material obtained by the questionnaire, the primary analysis of the opinions of various target groups has been conducted and the results compared.

Qualitative analysis has been complemented by quantitative analysis through applying the indicators of central tendency or location (arithmetic mean, mode, median), as well as indicators of variability (variance, standard deviation, standard error of mean, range, etc.). This has enabled us to draw conclusions regarding the research problem based on which further practical recommendations for possible steps in policy making could be prepared and taken.

\section{THE EMPIRICAL DATA ANALYSIS}

In the empirical study, the focus of the research was on the analysis and comparison of the opinions of entrepreneurs regarding the introduction of innovative approaches in VET. The empirical data analyses were based on the results of the survey of entrepreneurs in Iecava District, Latvia. The questionnaire consisted of closed and open questions concerning the introduction of innovative approaches, e.g. work-based learning in the VET system in Latvia and potential challenges for such reforms. Most of the questions were stated to evaluate on the scale 1-10 (where 1 - do not agree; 10 - fully agree) to discover the attitude of respondents to the questions. Responses to several questions were very different - views of the entrepreneurs were different and in some cases covered the entire scale. Among the questions asked to the respondents were:

1) Do you agree that innovative approaches in the VET system in Latvia should be introduced in order to train competitive labour force?

2) Do you in principle support the introduction of workbased learning in the Latvian VET system? Please, comment.

3) Would you be prepared, within the range of your competence, to support the implementation of workbased learning projects?

The main statistical indicators of the answers to those questions are presented in Table 1.

TABLE I

MAIN STATISTICAL INDICATORS OF ENTREPRENEUR RESPONSES ON THE ATTITUDE TOWARDS INNOVATIVE APPROACHES IN VET

\begin{tabular}{|l|c|c|c|}
\hline & $\begin{array}{c}\text { Do you in } \\
\text { principle support } \\
\text { the introduction of } \\
\text { work-based } \\
\text { learning in the } \\
\text { Latvian VET } \\
\text { system? }\end{array}$ & $\begin{array}{c}\text { Do you agree that } \\
\text { innovative approaches } \\
\text { in the VET system in } \\
\text { Latvia should be } \\
\text { introduced in order to } \\
\text { train competitive } \\
\text { labour force? }\end{array}$ & $\begin{array}{c}\text { Would you be } \\
\text { prepared to } \\
\text { support the } \\
\text { implementatio } \\
\text { n of work- } \\
\text { based learning } \\
\text { projects? }\end{array}$ \\
\hline Mean & 7.71 & 7.64 & 4.63 \\
Median & 8.00 & 8.00 & 4.50 \\
Mode & 10 & 8 and 10 & 1 \\
Std. Deviation & 2.462 & 2.264 & 3.090 \\
Range & 9 & 7 & 9 \\
Minimum & 1 & 3 & 10 \\
Maximum & 10 & 10 & 1 \\
\hline
\end{tabular}

Source: Authors' calculations based on survey results in 2013,

Evaluation scale $1-10$, where 1 - do not agree, 10 -fully agree

The results indicate that respondents had rather different opinions regarding the stated questions - most of the responses were evaluated with the highest grades. Comparatively less enthusiasm was expressed by the employers regarding their readiness to support the implementation of work-based learning in the region: arithmetic mean was only 4.63 points, half of the respondents evaluated it as less than 4.5 , half - with more than 4.5 (indicated by median), most often the evaluation for this statement was 1 . This indicates that not all employers are ready to accept implementation of vocational education activities in their company, but are willing to get well-trained labour force. The distribution of answers is represented in Figure 1 and shows that most of the entrepreneurs in general still support the introduction of work-based learning elements in the Latvian VET system. 


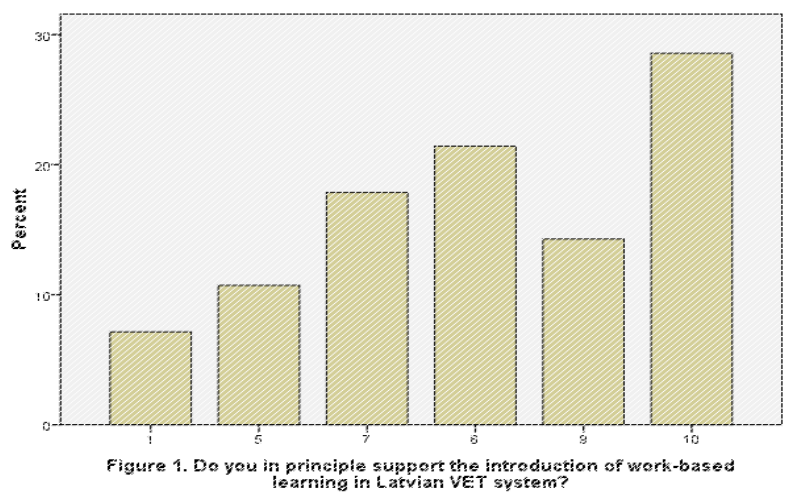

Fig. 1. Distribution of evaluations of entrepreneurs on introduction of work-based learning

Source: Author's calculations based on survey results in 2013,

Evaluation scale 1-10, where 1-do not agree, 10 - fully agree

Responses of entrepreneurs have indicated that most of them are highly supportive to the implementation of dual education system, and they gave the highest evaluations or close to the highest evaluations. However, there were also the lowest evaluations given by $7 \%$ of the entrepreneurs and there was a comment that such system was not needed. Still the survey results have indicated that employers in general support the introduction of work-based learning which is indicated by very high evaluations: arithmetic mean 7.71, half of the respondents gave evaluation 8 or less, half of the employers gave evaluation 8 or higher (indicated by median), the most frequent evaluation regarding this statement was with the highest evaluation (indicated by mode).

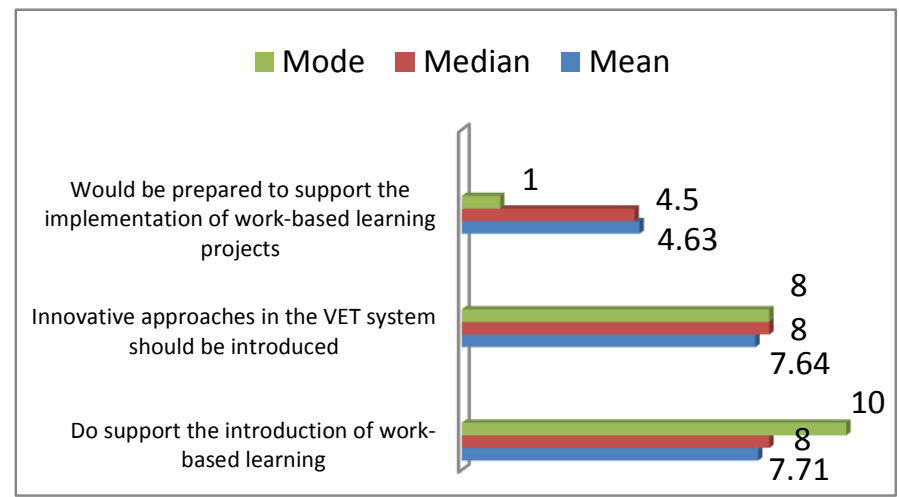

Fig. 2. Average evaluations of entrepreneurs on the statements regarding innovative approaches in VET system

Source: Author's calculations based on survey results in 2013

Evaluation scale 1 -10, where 1-do not agree, 10 -fully agree

The survey results indicated that there are different levels of readiness of employers to implement or accept the dual education or elements of dual education.

\section{CONCLUSIONS AND RECOMMENDATIONS}

The content analysis and the empirical study allow drawing conclusions about the relatively high level of readiness, need and conceptual strategic support to carry out VET reforms in relation to innovative approaches and work-based training elements in the Latvian VET system. The national and the EU policy documents offer a clear strategic framework for addressing the issue of youth employment and suggest concrete measures for achieving the desired goals, also taking into consideration the still present global economic downturn and its consequences. The academic discourse has direct links to the policy discourse on the above mentioned issues, and alongside with the analysis of conceptual approaches offer relevant case studies regarding innovative approaches to vocational education and training in the context of local and regional development. In Latvia, the entrepreneurs locally are aware of the challenges and the needed solutions for addressing the (youth) employment issues, acknowledge the need for innovative solutions in vocational education and training to bring it closer to the actual labour market and generally are also prepared to render their support to the implementation of such innovative solutions (projects). However, part of the surveyed expert questions indicated the need for the implementation of work-based learning approaches in Latvia. These issues require further studies regarding the preparedness of Latvian employers and other stakeholders to implement work-based learning approaches, as well as a study on the particular reasons for potentially supporting or, alternatively, for questioning the importance of the introduction of these approaches.

Suggestions and recommendations for the introduction of work-based learning and its linkage to national and regional development have to be developed further by politicians and public administrators at the national and regional level.

\section{REFERENCES}

[1] Asselt, R.V. "The First Large Scale CAI Experiment in the Higher and Advanced Vocational Education (HBO) in the Netherlands" in Higher Education and New Technologies, 1989, pp. 263-268.

[2] Betz, N. E., Borgen, F. H., Rottinghaus, P., Paulsen, A., Halper, C. R., Harmon, L. W. "The Expanded Skills Confidence Inventory: Measuring Basic Diomensions of Vocational Activity", in Journal of Vocational Behavior, Vol. 62, 2003, pp. 76-100. http://dx.doi.org/10.1016/S0001$\underline{8791(02) 00034-9}$

[3] Brunello, G., Comi, S. L., Sonedda, D. “Training Subsidies and the Wage Returns to Continuing Vocational Training Evidence from Italian Regions", in Labour Economics, Vol. 19, 2012, pp. 361-372. http://dx.doi.org/10.1016/j.labeco.2012.03.002

[4] Bubany, S. T., Hansen, J._I. C. "Birth Cohort Change in the Vocational Interests of Female and Male College Students", Journal of Vocational Behaviour, Vol. 78, 2011, pp. 59 - 67. http://dx.doi.org/10.1016/j.jvb.2010.08.002

[5] Council of the EU Resolution of 19 December 2002 on the promotion of enhanced European cooperation in vocational education and training (2003/C13/02). Official Journal of the European Communities. C $13 / 2.18 .1 .2003$.

[6] Deisinger, T. "Dual System", in International Encyclopedia in Education, $3^{\text {rd }}$. edit., 2010, pp. 448-454.

[7] Dlouha, J., Barton, A., Janouškova, S. "Social Learning Indicators in Sustainability - Oriented Regional Learning Networks", Journal of Cleaner Production, Vol. 49, 2013, pp. 64-73. http://dx.doi.org/10.1016/j.jclepro.2012.07.023

[8] Dlouha, J., Barton, A., Huisingh, D., Adomssent, M. "Learning for Sustainable Development in Regional Networks", Journal of Cleaner Production, Vol. 49, 2013, pp. 1-4.

http://dx.doi.org/10.1016/j.jclepro.2013.01.041

[9] Editorial, "Building New Approaches to Thinking about Vocational Education and Training and Development: Policy, Theory and Evidence”, International Journal of Education Development, Vol. 32, 2012, pp. 619-622. http://dx.doi.org/10.1016/i.ijedudev.2012.04.003

[10] European Commission (2010). Europe 2020: A strategy for smart, sustainable and inclusive growth. Brussels, 3.3.2010. COM(2010) 2020 final. 
[11] European Commission (2010). Youth on the Move. An initiative to unleash the potential of young people to achieve smart, sustainable and inclusive growth in the European Union. Brussels, 15.9.2010. COM(2010) 477 final

[12] European Commission (2010). A new impetus for European cooperation in Vocational Education and Training to support the Europe 2020 strategy. Brussels, 9.6.2010. COM(2010) 296 final.

[13] European Commission (2010). An Agenda for new skills and jobs: A European contribution towards full employment. Strasbourg, 23.11.2010. $\operatorname{COM}(2010) 682$ final.

[14] European Commission (2010). Working together for Europe's young people. A call to action on youth unemployment. Brussels, 19.6.2013. $\operatorname{COM}(2013) 447$ final.

[15] European Commission (2012). Proposal for a COUNCIL RECOMMENDATION On Establishing a Youth Guarantee. Brussels, 5.12.2012. COM(2012) 729 final. 2012/0351 (NLE).

[16] European Commission, Apprenticeship supply in the Member States of the European Union. Final Report. 2012, available also at http://ec.europa.eu/education/vocationaleducation/doc/forum12/supply_en.pdf [Accessed September 2, 2013].

[17] European Social Partners (2013). Framework of Actions on Youth Employment.

[18] Fidgeon, P.R. "Tourism Education and Curriculum Design: A Time for Consolidation and Review?" in Tourism Management, Vol. 31. 2010, pp. 699-723. http://dx.doi.org/10.1016/j.tourman.2010.05.019

[19] Gunning, D. Quality Assurance in Vocational Education and Training, in: International Encyclopedia of Education ( $3^{\text {rd }}$ edition), 2010, pp. 482-488.

[20] Heyes, J. Vocational training, employability and the post-2008 jobs crisis: Responses in the European Union, in: Economic and Industria Democracy, Vol. 34, 2013, pp. 34: 291.

[21] Hyghes, M., Hyghes, C. Industry involvement in the Vocational Education and Training System, in: International Encyclopedia of Education $\left(3^{\text {r }}\right.$ edition), 2010, pp. 455-462.

[22] Isgoren, N. C., Cinar, A., Tektas, N., Oral, B., Buyukpehlivan, G., Ulusman, L., Oznaz, D., Polat, Z., Uzmanoglu, S. The Importance of Cooperation Between Vocational Schools and Industry, in Procedia and Behavoiral Sciences, Vol. 1, 2009, pp. 1313-1317.

[23] Jarvis, J. and Peel, V. Tourists for hire: International working holidaymakers in a work based destination in regional Australia. Tourism Management, Vol. 37, 2013, pp. 114-124. http://dx.doi.org/10.1016/j.tourman.2012.10.014

[24] Karatzoglou, B. An In - Depth Literature Review of the Envolving Roles and Contributions of Universities to Education for Sustainable Development, in Journal of Cleaner Production, Vol. 49, 2013, pp. 44-53. http://dx.doi.org/10.1016/j.jclepro.2012.07.043

[25] King, K. Skills and Education for All: from Jontiem (1990) to the GMR (2012) - A Policy History in International Journal of Training Research, Vol. 9, 2011, pp. 16-34.

[26] Koundahl, P. D. Vocational Education and Training: Dual Education and Economic Crises, in: Procedia Social and Behavioral Sciences, Vol. 9, 2010, pp. $1900-1905$.

[27] Kraker, J., Cörvers, R., Valkering, P., Hermans, M., Rikers, J. Learning for sustainable regional development: towards learning networks 2.0 ? in Journal of Cleaner Production, Vol. 49, 2013, pp. 114-122. http://dx.doi.org/10.1016/j.jclepro.2012.11.019

[28] Lansu, A., Boon, J., Sloep, P.B. and van der Dam-Mieras, R. Changing professional demands in sustainable regional development: a curriculum design process to meet transboundary competence, in Journal of Cleaner Production, Vol. 49, 2013, pp. 123-133. http://dx.doi.org/10.1016/j.jclepro.2012.10.019

[29] Learmonth, A. and Pedler, M. Auto Action Learning: a tool for policy change. Building capacity across the developing regional system to improve health in the North East of England, in Health Policy, Vol. 68, 2004, pp. 169-181. http://dx.doi.org/10.1016/j.healthpol.2003.09.002

[30] Maclean, R., Pavlova, M. Planining and Policy Development for Technical Vocational Education and Training Systems, in: International Encyclopedia of Education ( $3^{\text {rd }}$ edition). 2010, pp. 469-475.

[31] Maliranta, M., Nurmi, S. and Virtanen, H. Resources in vocational education and post-schooling outcomes in International Journal of Mabpower, Vol. 31, Iss. 5, 2010, pp. 520-544

[32] McGrath, S. Building New Approaches to Thinking about Vocational Education and Training and Development: Policy, Theory and Evidence, in International Journal of Educational Development, Vol. 32, 2012, pp. 619-622. http://dx.doi.org/10.1016/j.ijedudev.2012.04.003
[33] McGrath, S. Education and Development: Thirty Years of Continuity and Change, in International Journal of Educational Development, Vol. 30, 2010, pp. 537-543. http://dx.doi.org/10.1016/j.ijedudev.2010.04.004

[34] McMahon, W. W., Hwa, J., Brediono, J. Vocational and Technical Education in Development: Theoretical Analysis of Strategic Effects on Rates of Return, in: Economics of Education Review, Vol. 11, iss. 3 , 1992, pp. 181-194. http://dx.doi.org/10.1016/0272-7757(92)90050-D

[35] Ministry of Welfare, Latvia. Active labour market policy measures 2012.

[36] National Development Plan of Latvia for 2014-2020, Cross-Sectoral Coordination Centre. Approved by a Decision of the Saeima on 20 December 2012.

[37] National Reform Programme of Latvia for Implementation of the Europe 2020 Strategy. Approved by a Decision of the Cabinet of Ministers, April 2011.

[38] Results of empirical research on European Social Fund project Research of Needs of Iecava Municipality for Realisation of EU and other Financial Institutions Co-Financed Projects and Activities are available on Iecava municipality webpage http://www.iecava.lv/page/621 [Accessed September 1, 2013].

[39] Ruth, K. and Deitmer, L. The Relationship between Technical and Vocational Education and Training and Innovation. International Encyclopedia of Education (3rd Edition), 2010, pp. 423-428.

[40] Sonnet, A. Off to a Good Start? Jobs for Youth. OECD Publishing. December 15, 2010

[41] Sotarauta, M. Power and influence tactics in the promotion of regional development: An empirical analysis of the work of Finnish regional development officers in Geoforum, Vol. 40, 2009, pp. 895-905.

[42] Stern, D., Finkelstein, N., Urquila, M., Caganpang, H. What Difference Does it Make if School and Work are connected? Evidence on Cooperative Education in United States, in Economics of Education Review, Vol. 16, Iss. 2, 1967, pp. 213-229.

[43] Sustainable Development Strategy of Latvia until 2030 (Latvia 2030). Approved by a Decision of the Saeima on 10 June 2010.

[44] The Copenhagen Declaration. 2002. Declaration of the European Ministers of Vocational Education and Training, and the European Commission, convened in Copenhagen on 29 and 30 November 2002, on enhanced European cooperation in vocational education and training.

[45] The European Trade Union Confederation, The Confederation of European Business, European Association of Small And Medium-Sized Enterprises, and The European Centre of Employers and Enterprises Providing Public Services.

[46] Tynjala, P. Perspectives into learning at the workplace, in Educational Research Review, Vol._3, 2008, pp. 130-154. http://dx.doi.org/10.1016/j.edurev.2007.12.001

[47] Van Uden, J. M., Ritzen, H., Pieters, J. M. Engaging Students: The Role of Teacher Beliefs and Interpersonal Teacher Behavior in Fostering Student Engangement in Vocational Education, in Teaching and Teacher Education, Vol. 37, 2014, pp. 21-32

http://dx.doi.org/10.1016/j.tate.2013.08.005

Ilze Buligina. MA (Cum Laude), Maastricht University, the Netherlands (2010), currently a PhD student at the University of Latvia.

The field of study is public administration. Currently working at the Ministry of Education and Science, Latvia. Ilze Buligina has coordinated and led several EU projects.

A recent publication: Buligina, I. \& Sloka, B. 2012. Approaches to Improved Institutional Mechanisms in Training Labour Force to Promote Innovation. 17th International Scientific Conference "Economics and Management-2012 (ICEM-2012, Tallinn, March 28-30, 2012. Published in the periodical "Economics and Management”, Vol. 17, No. 3, 2012, ISSN 1822-6515, pp. 816-822.

The research interests of Ilze Buligina concern public administration, responsible governance, labour force training to promote innovation. Ilze Buligina has received Top 3\% Student Award of Maastricht University in 2010. Address: Aspazijas Bulv. 5, Riga, University of Latvia, Faculty of Economics and Management, Latvia, LV - 1050.

Telephone and e-mail address: + 371 29478176, ilze.buligina@gmail.com.

Romans Putans. MA, Ph.D. Fellow, researcher and lecturer, University in Latvia. Romans Putans holds a Master Degree in European Studies.

Since 2009, he has been working as a researcher in the Centre for European and Transition Studies at the University of Latvia. In the period between 2002-2010 worked for the State Revenue Service of the Republic (SRS) of Latvia as a part of the SRS Modernization Project Unit (2002-2004), and later in the fields of project management, strategic analyses and development. His research interests relate to customer service and strategic planning in public administration. 
Address: Aspazijas Bulv. 5, Riga, University of Latvia, Faculty of Economics and Management, Latvia, LV - 1050.

Telephone and e-mail address: + 371 29442854, romansputans@gmail.com.

Biruta Sloka. Dr.oec., University of Latvia, educational background: economistmathematician, gained experience in Aaarhus University (Denmark), Dalhousie University (Canada), Oklohama State University (USA), Agder University (Norway), etc.

Biruta Sloka currently is a professor at the University of Latvia. She had experience in working at the Ministry of Economics and Ministry of Education and Science, was a coordinator of many international conferences and led several research projects.

Biruta Sloka is a member of the Association of Latvian Statisticians, Association of Professors of Latvian Higher Education Institutions, Association of Econometrists, Association of Hydrogen.

Address: Aspazijas Bulv. 5, Riga, University of Latvia, Faculty of Economics and Management, Latvia, LV - 1050.

Telephone and e-mail address: + 371 29244966, Biruta.Sloka@lu.lv.

Ilze Buligina, Romāns Putāns, Biruta Sloka. Darba vidē balstītas mācības saistībā ar reg̣ionālās attīstības jautājumiem

Raksts ir veltîts jaunu risinājumu ieviešanas jautājumiem Latvijas profesionālās izglîtības sistēmā saistībā ar jauniešu kā konkurētspējīga darbaspēka sagatavošanas jautājumiem, īpaši akcentējot reǵionālo kontekstu. Pieeja izriet no literatūras analīzes rezultātā konstatētās tendences par iesaistīto pušu skaita un darbības jomu pieaugumu, kā arī savdabības formu dažāasošanos, nodrošinot reǵionu ekonomiskajai attīstībai nepieciešamo darbaspēku. Literatūras analīze balstīta uz Eiropas Savienības un Latvijas mēroga politiskajiem dokumentiem un iniciatīvām, kas nepārprotami akcentē nepieciešamību tuvināt mācību un darba vidi, meklējot tam jaunus un katrai valstij piemērotus risinājumus.

Līdztekus literatūras analīzei, raksts balstīts arī uz empīriskajiem pētījumiem, kas tika veikti Eiropas Sociālā fonda atbalstītā projekta „Iecavas novada vajadzību izpēte ES un pārējās ārvalstu finanšu palīdzības līdzfinansēto projektu un pasākumu īstenošanā” ietvaros. Pētijumā noskaidroja Iecavas novada uzṇēmēju un citu iesaistîto pušu viedokḷs par to, cik lielā mērā tie ir gatavi jaunu darba vidē balstītu pieeju īstenošanā, nodrošinot ciešāku sasaisti starp profesionālo izglītîbu un uzṇēmumu. Galvenais akcents pētijumā likts tieši uz darba vidē balstītu pieeju ieviešanu, kas Latvijas apstākḷos uzskatāma par jaunu pieeju, lai gan ilgu laiku tiek īstenota vairākās Eiropas valstīs. Empīriskajā izpētè ekspertu vērtējumus analizēja, izmantojot centrālās tendences jeb lokācijas rādītājus, variācijas rādīiājus, kā arī grupējumus pēc dažādām pazīmēm. Analīzes rezultātā tika izdarīit secinājumi, ka darbaspēka sagatavošanas jautājumos uzṇēmēji kopumā atbalsta jaunu, tajā skaitā darba vidē balstītu, pieeju īstenošanu Latvijā, bet tikai dą̧̣eji ir gatavi paši aktīvi piedalīities šo pieeju īstenošanā praksē, tajā skaitā uz darba vidē balstîtām mācībām. Pêtījuma rezultātā gūtās atzinas izmantojamas tālākos pētijumos par minētajiem jautājumiem, kā arī rekomendāciju sniegšanai politikas veidotājiem.

Илзе Булигина, Романс Путанс, Бирута Слока. Связь образования, базирирующегося на рабочей среде, с вопросами регионального развития. Статья посвящена новым подходам в профессиональном образовании Латвии в подготовке профессиональной рабочей силы, уделяя особое внимание региональному акценту и готовности разных заинтересованных сторон (предпринимателей, руководства муниципалитетов, сотрудников просвещения и обучаемых) найти самые плодотворные формы сотрудничества и разнообразия этих форм сотрудничества. Для эмпирического анализа использованы результаты опроса предпринимателей, результаты фокусных групп о готовности к внедрению новых форм обучения. Для анализа статистической информации использованы показатели центральной тенденции или локации - арифметические средние, моды, медианы, и также показатели или вариации колебаний. В результате анализа сделаны выводы что предприниматели в основном поддерживают внедрения новых форм подготовки квалифицированных специалистов в том числе дуальной системы или обучении основанном в рабочей среде в Латвии но только частично готовы внедрять их на практике и принять обучаемых на своем предприятии. Новшества в исследовании будут использованы в дальнейшей работе по исследованиям намеченных вопросов а также подготовке предложений и рекомендаций для принятия политических решений. 